\title{
URALITIZATION - AN EXAMPLE FROM KUUSAMO, FINLAND
}

\author{
RISTO PIISPANEN and TUOMO ALAPIETI
}

\begin{abstract}
PIISPANEN, RISTO and ALAPIETI, TUOMO 1977: Uralitization - An example from Kuusamo, Finland. Bull. Geol. Soc. Finland 49, $39-46$.

The course of events as well as the chemical changes associated with the alteration of clinopyroxenes to uralite have been studied from diabases in Kuusamo, Finland. The uralitization takes place in several phases starting from the intercumulus spaces, where latemagmatic fluids cause an increase in iron and titanium in the pyroxene as a first phase of alteration. During the second phase the pyroxene is altered to actinolitic amphibole which appears as isolated flakes within the pyroxene, later the entire pyroxene crystal becomes filled with colourless amphibole. At this stage $\mathrm{Fe}$, Ti, Al and $\mathrm{K}$ and $\mathrm{Na}$ are introduced internally from the rock-mass itself into the altering mineral. Some $\mathrm{Ca}$ is removed simultaneously. Finally, the amphibole changes into a green hornblende with additional introduction of the above elements. During the last phase the crystal boundaries of the original pyroxene are exceeded and the amphibole overflows from the pyroxene crystal spaces at the expense of the adjoining plagioclase that participates in the reaction.

The density of the uralitized rock is somewhat lower than that of an unaltered counterpart. It is postulated that some silica is removed during the process to account for the drop in the density.
\end{abstract}

Risto Piispanen and Tuomo Alapieti, Department of Geology, University of Oulu, SF-90100 Oulu 10, Finland.

\section{Introduction}

The term uralitization is generally accepted to describe an alteration of either an ortho- or a clinopyroxene to amphibole so that the original crystal form of the pyroxene is preserved or still discernible. As the definition implicitly states the process can take place in magmatic as well as in metamorphic environments. The term was probably first used by Gustav Rose in the description of his travels in the southern Ural Mountains (Rose 1842 in Tröger 1935, p. 336).
Historically, the alteration was long deemed a metamorphic phenomenon during the last part of the 19th and the beginning of the present century. In the 1880's Fr. Becke created the so-called volume law applicable to metamorphic events. As uralitization was looked upon as a metamorphic phenomenon it was only natural to scrutinize it from the standpoint of the volume law. The law stated that in order to cope with the requirements of the high pressure prevailing during the metamorphism, minerals of higher density should replace the original 
mineral assemblage. It was therefore confusing to discover that in spite of the volume law the uralitic amphibole was found to be lighter than the original pyroxene and that the volume law was simply inapplicable to uralitization.

The defenders of the volume law pointed out that volume of water necessary for the alteration should also be taken into consideration in the discussion of the volume-density relationships. In Finland Eskola and Sederholm examined uralitization from the standpoint of the volume law (Eskola 1914 and 1915, Sederholm 1891 and 1926). Eskola was able to show based on his calculations of normative chemical composition, that uralitization did not obey the volume law except in special cases where a blue-green amphibole was formed during the process (Eskola 1915, pp. 143-5). Eskola's material came from the metamorphic uralite porphyrites of southern Finland and therefore he seems to have looked upon uralitization as a purely metamorphic phenomenon.

Sederholm (1926) concluded the uralite discussion for a long time in 1926 when following Eskola he emphasized that the process contravened the volume law. He also drew attention to the density drop associated with uralitization. He pointed out that Eskola's calculations were subject to some uncertainty since they were merely theoretical. Sederholm wanted to dispel this uncertainty by using density determinations of two rocks, one of which represented an unaltered pyroxene rock and the other, what he called, a »c orresponding» uralitized rock. By a »corresponding» rock he seems to have meant a rock of the same chemical composition. If a constant composition is assumed to remain after the events leading to uralitization, the problem is solved beforehand. The only point requiring an explanation is the drop in density, which then has only one explanation, the expansion of the rock-mass.
The densities of the rocks were according to Sederholm 3.08 and $2.85 \mathrm{~g} / \mathrm{cm}^{3}$ respectively. No explanation, however, is given either by Eskola or Sederholm as to the density drop.

To summarize the problems associated with the uralitization process, one might ask what chemical changes are there in the mineral itself when a pyroxene alters to uralite? If there are chemical changes, are the components transported internally within the rock-mass or is there a material exchange with the surroundings? In other words, does the whole-rock chemical composition change during the process? If there is transport of material, where are the components derived from or where do they go if something is removed? How is the density drop associated with uralization, which seems to be a verified fact, to be explained? Does the volume of the rock-mass expand or is there a material deprival that makes the rock-mass lighter?

\section{Earlier work}

After the publication of Sederholm's (1926) paper mentioned above there seems to have been a long period during which uralitization provoked little interest among petrologists. In 1951, Oliver studied the chemical changes associated with uralitization in the Sudbury norite (Oliver 1951). In Sudbury, an orthopyroxene has undergone uralitization. According to Oliver, the chemical changes involved are very small and mostly within the range of experimental error, only a slight a d di$\mathrm{t}$ i o $\mathrm{n}$ of silica and alumina possibly has any significance. Similarly, Allen and Fahey (1957) arrived at the same kind of conclusions. According to these authors uralitization means an increase of $\mathrm{Si}, \mathrm{Al}, \mathrm{Fe}, \mathrm{Ti}, \mathrm{Mn}$ and $\mathrm{H}_{2} \mathrm{O}$ as well as a removal of $\mathrm{Ca}$ in the mineral: the whole-rock chemistry is not discussed. Panto (1969) reported a slight increase of $\mathrm{Si}, \mathrm{Al}, \mathrm{Ca}$ and $\mathrm{H}_{2} \mathrm{O}$ in association with the uralitization of an orthorhombic pyroxene. 


\section{Material and method}

For the present study diabases described earlier by one of us (Piispanen 1972) from the Kuusamo Presvecokarelian basement gneiss complex in northeastern Finland were subjected to further investigation. The diabases form a series from fresh pyroxene diabases to completely altered uralite diabases with all intermediate stages present. The original pyroxene is a subcalcic augite or an augite. No lamellar structure can be observed under the microscope.

The minerals were analysed using a JEOL JXA-3SM electron microprobe. Five uralitized pyroxene grains were examined using a 3-pen recorder and $3-5$ quantitative point analyses were made from five different mineral grains. Quantitative analyses were carried out using a $15 \mathrm{kV}$ accelerating voltage, $0.05 \mu \mathrm{A}$ specimen current (measured on $\mathrm{Cu}$-metal) and 10 second counting time. The standards used were: quartz for $\mathrm{Si}$, $\mathrm{TiO}$ for $\mathrm{Ti}$, synthetic sapphire for $\mathrm{Al}$, haematite for $\mathrm{Fe}$, periclase for $\mathrm{Mg}$, wollastonite for $\mathrm{Ca}$, potash feldspar for $\mathrm{K}$ and albite for $\mathrm{Na}$. ZAF corrections were processed by the computer program MK2 (Mason, Frost and Reed 1969) using a UNIVAC 1108 computer. The variation of the main element contents were measured along profiles (see Fig. 1) from the fresh unaltered pyroxene in the centre of the grain through the various uralite zones as far as the outer edge of the grain where normally a green hornblende occurs.

Chemical changes in the whole-rock bulk chemical composition during uralitization were studied by using whole-rock silicate analyses of the fresh and altered diabases (Table 3). The densities of the rocks were also determined (see Fig. 7).

\section{Phases of uralitization}

A microscopic study of the diabases reveals a multiphase nature of the process. The alter-

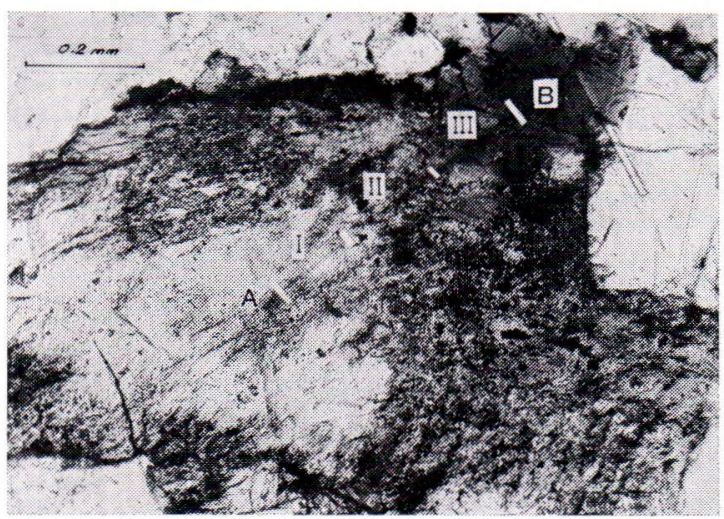

Fig. 1. Photomicrograph showing an example of an electron microprobe run across a grain under uralitization. The trace of the electron beam can faintly be seen from the middle (A) to the upper right (B). Run 599/2. Without analyzer. For zone connotation and the chemical composition of the various zones see Fig. 6 and Table 1. Pyroxene diabase, $150 \mathrm{~m}$ NE of Lamminmäki, Sarviperä, Kuusamo.

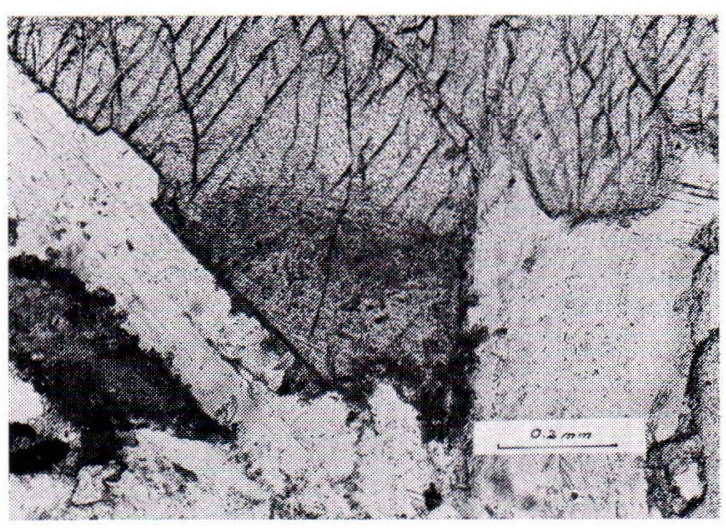

Fig. 2. The initial stage of uralitization. The alteration starts from the intercumulus spaces (lower middle), the rest of the grain remaining unaltered. Pyroxene diabase, Kalliovaara, Kuusamo. (555D). Without analyzer.

ation takes place in several phases one after another and the resulting stages can be seen under the microscope. The process starts from the intercumulus pore spaces, where usually late-crystallizing minerals such as quartz and alkali feldspar and the corresponding graphically intergrown material is concentrated. Obviously, owing to the increasing pressure in the ever-diminishing spaces, the fluid fi- 


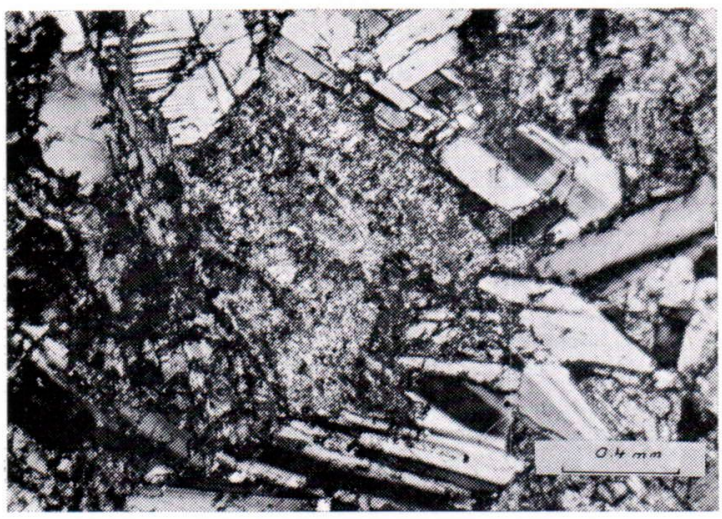

Fig. 3. Photomicrograph of a pyroxene grain completely altered to colourless flaky amphibole. Uralite pyroxene diabase, Sarviperä, Kuusamo. (598). Crossed polarizers.

nally begins to encroach upon the surrounding pyroxene (see Fig. 2). It is interesting to note that the grain is totally unaltered from everywhere else except in the vicinity of the intercumulus pore spaces. This phase of alteration indicates the introduction of iron and tíanium into the pyroxene as small opaque grains, the pyroxene remaining otherwise unaltered.

During the second phase small flakes of colourless actinolitic amphibole start to appear within the pyroxene; they increase in number and volume and at the end of this phase they fill the entire space previously occupied by former pyroxene crystals (Fig. 3). Chemically, this means that $\mathrm{Fe}, \mathrm{Ti}, \mathrm{Al}, \mathrm{K}$ and $\mathrm{Na}$ are introduced to the altering crystal from outside and $\mathrm{Ca}$ is transported from the mineral grain (see II, Fig. 6). Whether this material transport is of an internal or external nature from the point of view of the rock-mass is discussed below.

After the colourless amphibole has filled the entire space of the former pyroxene crystals, green hornblende begins to form at the outer edges of the grains. The green amphibole overflows the former pyroxene crystal boundaries. This process takes place at the expence of the adjoining plagioclase crystals,

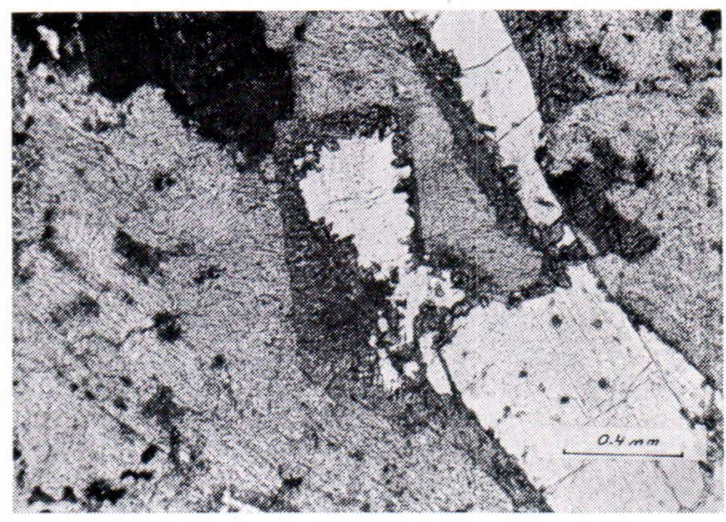

Fig. 4. Photomicrograph showing hornblende replacing plagioclase (middle of the picture) at the final stage of uralitization. Without analyzer. Uralite diabase, Iso Murtolampi, Kuusamo. (472).

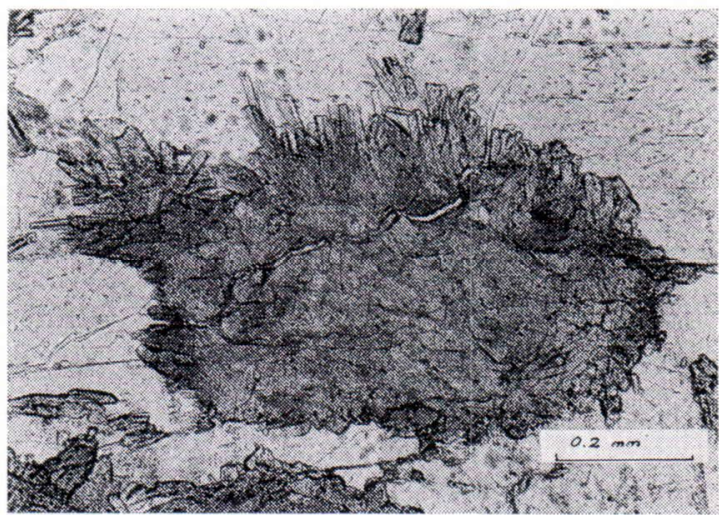

Fig. 5. Photomicrograph showing a detail of the allotriomorphic-granular texture resulting from uralitization. The original field of pyroxene can be seen faintly as a somewhat lighter area in the middle of the grain. Without analyzer. Uralite diabase, Iso Murtolampi, Kuusamo. (472).

the amphibole literally "eats up» the plagioclase as is shown in Fig. 4. Simultaneously, the amphibole within the original pyroxene crystals also becomes green and at the end of the process all the amphibole is of a green colour. It occupies the spaces of the former pyroxene crystals together with some of the space of the adjoining plagioclase crystals. As a result of the overflow the entire texture of the rock is converted from intersertal into an allotriomorphic-granular texture (Fig. 5). 

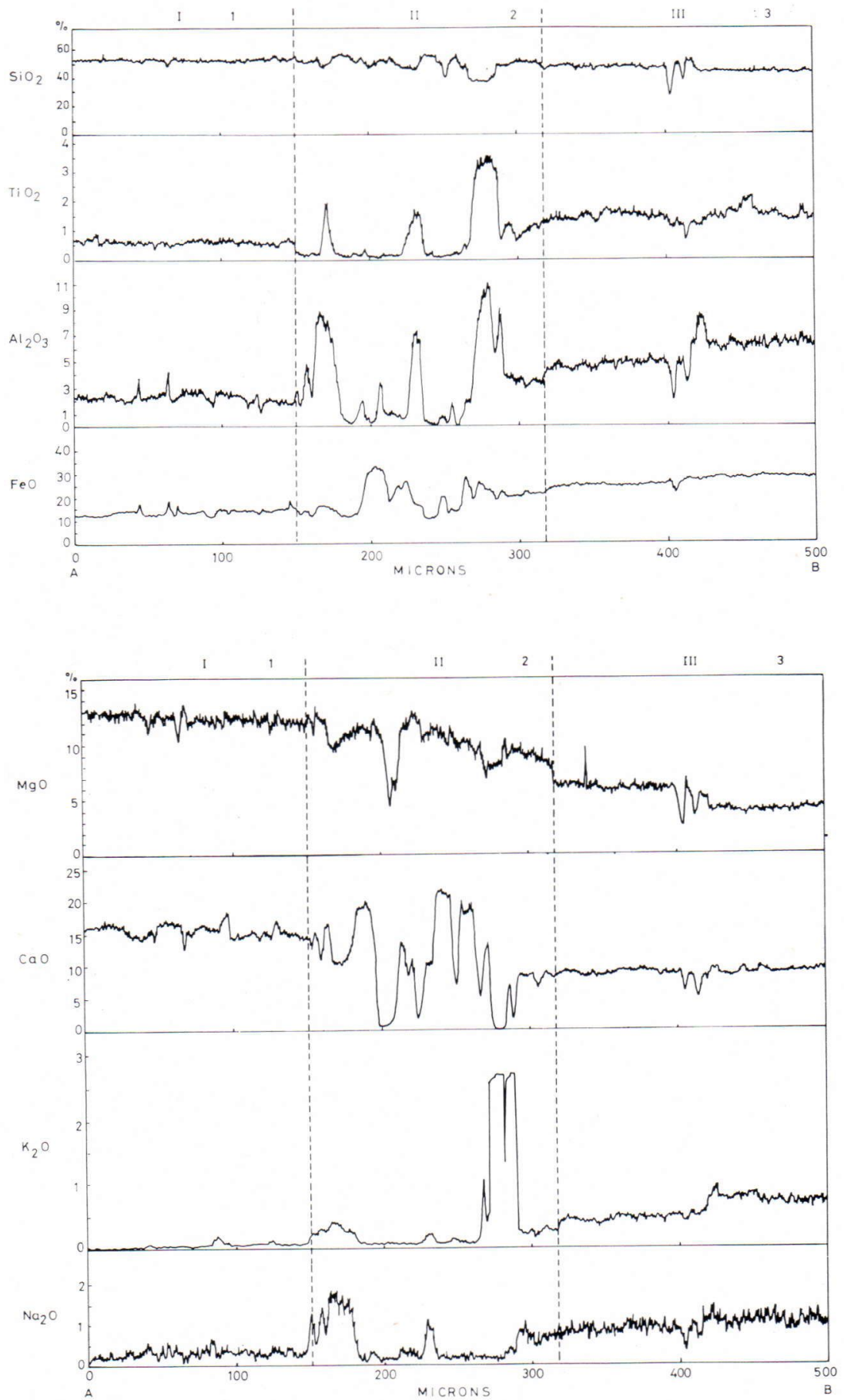

Fig. 6. Fluctuation of chemical composition in various zones of a grain under uralitization. The diagram has been redrawn after the original electron microprobe 3-pen recorder graphs. For the zone connotation (I, II and III) see Table 1, where the results of the analyses at points 1,2 and 3 are also given. Run 599/2. The start of the run is marked A in Fig. 1 . The disturbances at about 280 microns are due to an inclusion of biotite. 


\section{Chemical changes within the mineral grain}

A study of the chemical changes within a pyroxene grain during uralitization is rendered difficult by the fact that there are differences in the chemical composition between the different parts and zones of the pyroxene crystal. This results from the zonal structure of the grains. In order to eliminate the effect of the zoning only the changes that exceeded those expected on the basis of an assumed linear model of zonal structure were accepted as relevant to the uralitization problem. In Table 2 two plus-signs indicate a change stronger than that expected on the basis of the zonal pattern. Those changes marked with only one plus or minussign can be explained as a result of the zonation. Zone I designates the fresh pyroxene centre, zone II the colourless amphibole and zone III the green hornblende zone, respectively. Between the various zones level-like drops and rises in element contents can also be observed (see Fig. 6). These are the changes that are most easily accepted as not being caused by the zonary structure.

During the formation of colourless amphibole (I/II in Table 2) Ti, $\mathrm{Al}, \mathrm{Fe}, \mathrm{Na}$ and $\mathrm{K}$ are introduced into the altering mineral grain (see Fig. 6 and Table 1). These substances are gained from the in'tercumulus pore spaces that still contain material in the fluid state. Simultaneously, the mineral is impoverished in Ca.

During the last phase the formation of green hornblende at the outer edges of the grains takes place at the expense of the adjoining plagioclase, the feldspar participating in the reaction. The necessary $\mathrm{Na}$ and $\mathrm{Al}$ for the formation of the hornblende are obviously gained from the plagioclase, $\mathrm{Fe}$ and $\mathrm{Ti}$ being derived from the intercumulus fluids as before.
Table 1. Chemical composition of the various zones in a pyroxene grain under uralitization. Zone I denotes the fresh pyroxene centre, zone II the colourless actinolitic zone and zone III the green hornblende zone. The number of cations in the various zones are presented in the lower part of the table, calculated on the basis of 6 oxygens. Run 599/2. Pyroxene diabase $150 \mathrm{~m} \mathrm{NE}$ of Lamminmäki, Sarviperä, Kuusamo. (Whole-rock analysis of the rock is in Table 3 no. 599).

\begin{tabular}{|c|c|c|c|c|c|c|}
\hline & Zone I & & Zone II & & Zone III & \\
\hline $\mathrm{SiO}_{2}$ & 52.5 & & 49.4 & & 45.1 & \\
\hline $\mathrm{TiO}_{2}$ & 0.60 & & 1.09 & & 1.32 & \\
\hline $\mathrm{Al}_{2} \mathrm{O}_{3}$ & 2.70 & & 3.79 & & 6.63 & \\
\hline $\mathrm{FeO}_{\text {tot }}$ & 15.8 & & 21.4 & & 30.1 & \\
\hline $\mathrm{MnO}$ & 0.35 & & 0.37 & & 0.34 & \\
\hline $\mathrm{MgO}$ & 12.7 & & 9.65 & & 3.53 & \\
\hline $\mathrm{CaO}$ & 15.0 & & 9.02 & & 9.46 & \\
\hline $\mathrm{Na}_{2} \mathrm{O}$ & 0.27 & & 0.73 & & 1.20 & \\
\hline $\mathrm{K}_{2} \mathrm{O}$ & 0.00 & & 0.21 & & 0.79 & \\
\hline $\mathrm{Si}$ & 1.976 & & 1.973 & 00 & 1.848 & \\
\hline $\mathrm{Al}$ & 0.024 & & 0.027 & .00 & 0.152 & \\
\hline $\mathrm{Al}$ & 0.095 & & 0.151 & & 0.168 & \\
\hline $\mathrm{Ti}$ & 0.017 & & 0.033 & & 0.041 & \\
\hline $\mathrm{Fe}^{3+}$ & - & & - & & - & \\
\hline $\mathrm{Fe}^{2+}$ & 0.497 & & 0.715 & & 1.031 & \\
\hline Mg & 0.712 & 1.96 & 0.574 & 1.94 & 0.216 & 2.02 \\
\hline Mn & 0.011 & & 0.013 & & 0.012 & \\
\hline $\mathrm{Ca}$ & 0.605 & & 0.386 & & 0.415 & \\
\hline $\mathrm{Na}$ & 0.020 & & 0.057 & & 0.095 & \\
\hline $\mathrm{K}$ & 0.000 & & 0.011 & & 0.041 & \\
\hline
\end{tabular}

Table 2. Trends of changes in chemical composition between the various zones in a grain under uralitization. I/II denotes the change from a fresh pyroxene centre to a colourless actinolitic zone and II/III the change from the preceding to a green hornblende zone. The two plus-signs denote an increase stronger than that expected on the basis of zoning, those changes that are marked with only one sign may be due to the zonal structure.

Zone I/II

Zone II/III

\begin{tabular}{lcc}
\hline $\mathrm{Si}$ & $-\overline{+}$ & $+\overline{+}$ \\
$\mathrm{Ti}$ & ++ & ++ \\
$\mathrm{Al}$ & $\overline{-}$ & $+\overline{+}$ \\
$\mathrm{Mg}$ & ++ & $+\overline{+}$ \\
$\mathrm{Fe}(\mathrm{FeO})$ & $\overline{+}$ & ++ \\
$\mathrm{Ca}$ & ++ & \\
$\mathrm{Na}$ & & \\
$\mathrm{K}$ & & \\
\hline
\end{tabular}

\section{Change in density of the rock during uralitization}

A slightly lower density seems to be typical for all uralitized rocks when compared with 


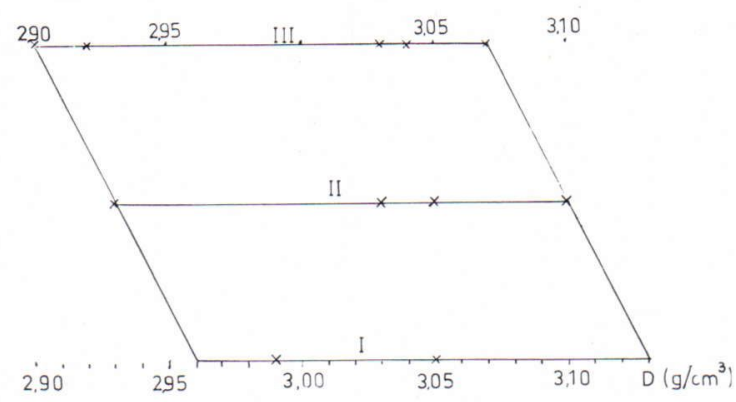

Fig. 7. The span of densities in the various diabase groups. I denotes the fresh unaltered diabases, II partly uralitized diabases and III totally uralitized diabases. The actual determinations are marked with crosses, the inferred total span of densities in the individual groups is also shown.

fresh rocks. Sederholm (1926) reported densities such as 3.08 and 2.85 for the fresh pyroxene rock and the corresponding (cf. p. 40) uralitized rock respectively. Eskola had come (1915, p. 144) to somewhat similar conclusions on the basis of calculations he made starting from a composition of an amphibolite and computing the normative mineral composition of a corresponding pyroxene rock.

The results of the density determinations made by the present writers are listed in Fig. 7. Due to the difficulties of knowing which rocks correspond to each other, the rocks are treated as groups of fresh, partly altered and totally altered rocks. The difficulties involved in knowing the correspondence of individual rocks were mentioned in passing above. The assumption that the corresponding rocks have the same chemical composition is solving the uralite problem beforehand. Similarly, the assumption that those rocks which contain the same amount of plagioclase correspond to each other can not be made since the amount of plagioclase diminishes during the process as was shown in the description of alteration above.

In Fig. 7 the actual density determinations are marked with small crosses. The diagram also shows the inferred span of densities that the members of the groups might have if all the possible rocks, i.e. those richest and poorest in plagioclase, could be sampled.

The span of the density values within the individual groups shows a slight shift towards the left in the figure from the fresh pyroxene rocks through the partly altered to the totally altered rocks. This suggests a slight decrease in density during uralitization.

\section{Changes in the whole-rock chemical composition during uralitization}

In order to become lighter a rock must gain a larger volume or loose some of its ma-

Table 3. Whole-rock chemical and mineralogical compositions of diabases showing the various stages of uralitization. Note the close resemblance (excepting $\mathrm{SiO}_{2}$ and $\mathrm{H}_{2} \mathrm{O}$ ) between 599 and 585 in spite of the differing amounts of plagioclase. Analyst for 599 and 594 P. Ojanperä and for 585 R. Saikkonen (Analyses earlier published in Table 3, p. 19 in Piispanen, 1972).

\begin{tabular}{lrrr}
\hline & 599 & 594 & 585 \\
\hline $\mathrm{SiO}_{2}$ & 50.49 & 51.66 & 49.00 \\
$\mathrm{TiO}_{2}$ & 2.06 & 1.74 & 1.95 \\
$\mathrm{Al}_{2} \mathrm{O}_{3}$ & 12.31 & 12.92 & 12.41 \\
$\mathrm{Fe}_{2} \mathrm{O}_{3}$ & 3.79 & 0.93 & 3.67 \\
$\mathrm{FeO}$ & 12.85 & 14.60 & 13.84 \\
$\mathrm{MnO}$ & 0.23 & 0.22 & 0.28 \\
$\mathrm{MgO}$ & 5.02 & 4.59 & 5.36 \\
$\mathrm{CaO}$ & 9.13 & 9.07 & 9.03 \\
$\mathrm{Na} 2$ & 2.39 & 2.25 & 2.48 \\
$\mathrm{~K}_{2} \mathrm{O}$ & 0.61 & 0.91 & 0.67 \\
$\mathrm{P}_{2} \mathrm{O}_{5}$ & 0.20 & 0.27 & 0.21 \\
$\mathrm{CO}$ & 0.15 & 0.00 & 0.00 \\
$\mathrm{H}_{2} \mathrm{O}+$ & 0.56 & 1.00 & 1.36 \\
$\mathrm{H}_{2} \mathrm{O}^{-}$ & 0.04 & 0.04 & 0.06 \\
\cline { 2 - 4 } & 99.83 & 100.0 & 100.32
\end{tabular}

Mineral composition

\begin{tabular}{lrrr}
\hline plagioclase & 54.4 & 33.0 & 34.0 \\
pyroxene & 33.2 & 32.8 & 0.0 \\
amphibole & 7.5 & 28.0 & 61.2 \\
opaque & 4.0 & 2.1 & 3.8 \\
quartz & 0.5 & 0.1 & 0.8 \\
accessories & 0.4 & 4.0 & 0.2 \\
\cline { 2 - 4 } & 100.0 & 100.0 & 100.0
\end{tabular}

599. Pyroxene diabase $150 \mathrm{~m} \mathrm{NE}$ of Lamminmäki, Sarviperä, Kuusamo

594. Uralite pyroxene diabase, southern shore of Lake Kalliolampi, Kuusamo

585. Uralite diabase, Veijola, Sarviperä, Kuusamo 
terial. An increase of volume during uralitization is deemed unlikely by the present writers; expansion would lead to fragmentation and crushing of the rock of which there is no textural sign. A material deprival seems to be a more likely solution. The material removal must first counterbalance the introduction of surplus water into the uralitizing rock. The increase of water is readily seen in the analyses in Table 3 . The question then remains what element or elements have left the system to account for the drop in the density in spite of the introduction of the extra water? The figures in the analysis table
(Table 3 ) indicate that during the uralitization process some silica has been removed, the uralitized rocks being poorer in silica than the fresh rocks.

The behaviour of silica in association with the uralitization of a clinopyroxene seems to be the opposite of what happens in the uralitization of an orthopyroxene where the addition of silica probably occurs. (Oliver 1951, Allen and Fahey 1957, Panto 1969).

Acknowledgement. Dr. P. L. Gibbard, University of Cambridge, U. K., kindly read the manuscript and deserves our warmest thanks for correcting the language.

\section{References}

Allen, V. T. and Fahey, J. J. (1957) Some pyroxenes associated with pyrometasomatic zinc deposits in Mexico and New Mexico. Bull. Geol. Soc. Am. 68: 881-896.

Eskola, P. (1914) On the petrology of the Orijärvi region in southwestern Finland. Bull. Comm. Géol. Finlande 40.

Eskola, P. (1915) Om sambandet mellan kemisk och mineralogisk sammansättning hos Orijärvitraktens metamorfa bergarter. Bull. Comm. Géol. Finlande 44.

Mason, P. K., Frost, M. T. and Reed, S. J. B. (1969) IMS Report 2. National Physical Laboratory, Teddington, Middlesex, England.

Oliver, T. A. (1951) The effect of uralitization upon the chemical composition of the Sudbury norite. Am. Mineral. 36: 421-429.

Panto, G. (1969) Textural, mineralogical and alteration characteristics of the Börzsöny
Mountains volcanic rocks. Acta Geol. Acad. Sci. Hungaricae 13: 277-302.

Piispanen, R. (1972) On the spilitic rocks of the Karelidic belt in western Kuusamo, northeastern Finland. Acta Univ. Ouluensis, Ser. A (4). Geol. 2.

Sederholm, J. J. (1891) Studien über Archäische Eruptivgesteine aus dem südwestlichen Finnland. Tschermaks Mineral. Petr. Mitt. 12: 97142.

Sederholm, J. J. (1926) On migmatites and associated pre-Cambrian rocks of southwestern Finland. Part II. The region around the Barösundsfjärd W. of Helsingfors and neighbouring areas. Bull. Comm. Géol. Finlande 77.

Tröger, W. E. (1935) Spezielle Petrographie der Eruptivgesteine. Berlin.

Manuscript received, September 23, 1976. 